\title{
DRIP IRRIGATION AS A FACTOR MITIGATING DROUGHT IMPACT IN CORN CULTIVATION IN CENTRAL POLAND
}

\begin{abstract}
Jacek ŻARSKI, Department of Land Reclamation and Agrometeorology, Faculty of Agriculture and Biotechnology, UTP University of Science and Technology, ul. Bernardyńska 6, 85-029 Bydgoszcz, Poland; zarski@utp.edu.pl

Stanisław DUDEK, Department of Land Reclamation and Agrometeorology, Faculty of Agriculture and Biotechnology, UTP University of Science and Technology, ul. Bernardyńska 6, 85-029 Bydgoszcz, Poland; dudek@utp.edu.pl

Renata KUŚMIEREK-TOMASZEWSKA, Department of Land Reclamation and Agrometeorology, Faculty of Agriculture and Biotechnology, UTP University of Science and Technology, ul. Bernardyńska 6, 85-029 Bydgoszcz, Poland; rkusmier@utp.edu.pl (corresponding author)
\end{abstract}

The aim of the paper was to develop a model determining production effects of corn irrigation depending on a drought level in the growing season.Corn is particularly useful for cultivation in the conditions of irrigation since its yield in central Poland depends significantly on rainfall distribution in growing season. Corn was grown under irrigation conditions in the years 2005-2016 in the region of central Poland, meteorological data, were gained from the research station of the UTP University of Science and Technology in Bydgoszcz. Based on the results of twelve-year effects of corn irrigation and meteorological data, the most relevant relationships between irrigation productivity and chosen indices during the period of high water needs of corn (from 1 June to 31 July) were searched. The following indicators were taken into account: absolute precipitation totals, relative precipitation index (RPI), standardized precipitation index (SPI) and the ratio of precipitation to reference evapotranspiration. The results shown that yield of non-irrigated corn were characterized by a very high variability and depended significantly on indicators, based mainly on rainfall conditions. The production effects of drip irrigation correlated significantly with the indicators during the period of high water needs of plants, covering June and July. In wet periods the increases in grain yields due to irrigation were non-significant and about four-fold lower and in the dry seasons - more than half higher than the average increases. There is a high importance of the results presented in the paper, because they can be used as a model for forecasting corn production and its economic effects as well as for planning the development of irrigation systems in a given area.

Keywords: drip irrigation, corn yield, drought index, atmospheric precipitation, evapotranspiration

\section{INTRODUCTION}

Plants cultivation in Poland is exposed to a climate risk resulting from the occurrence of precipitation-free drought periods. Such periods occur most often in the lowland central part of Poland, which is the key plant production area. Atmospheric droughts turning into soil droughts, and in some cases even into hydrological droughts, are in that area a frequent and irregular phenomenon. Their high intensity and range have been observed in the last 30 years in the 1989 , 1992, 2000, 2003, 2008 and 2015 growing seasons (Labędzki, 2006, Żarski et al., 2016, Żarski et al., 2017).

The occurrence of drought in the period of intensified water requirements deteriorates yielding, both in terms of quantity and quality. The agrotechnical practice, which is effective in preventing the negative effects of droughts, is irrigation. As reported by numerous researchers, it ensures the right rhythm of plant growth and development as well as intensifies physiological processes. Consequently, it results in a yield increase and its stability as well as enhances the yield quality (Rolbieckiet al., 2000, Rolbiecki et al., 2015, Wszelaczyńska et al., 2015, Żarski et al., 2013). An increase in the irrigated acreage in Poland, despite the growth observed, has been still a solution for the future and it is a serious agricultural production reserve. The factors speeding up the development of irrigation, next to ensuring higher and stable good-quality yields, include a need of enhanced modernization and competitiveness of agricultural farms and forecast climate changes (Łabędzki, 2009, Rzekanowski et al., 2011).

The plant, which is especially useful for growing in irrigated fields, is corn the importance of which is determined mostly by grain production (Dudek et al., 2009, Ko and Puccinni, 2009, Kuscu et al., 2013, Nagy, 2003, Parizi et al., 2016). The corn grain plantation acreage in Poland, located mostly in central Poland, in 2012-2016 was about 600 thousand ha and it was almost two-fold higher than in 2005-2011. One of the reasons of a considerably high variation in yields in respective years are water deficits. As reported by Żarski et al. (2017), corn grain yields in central Poland depend

Copyright (C) 2017 The Authors. Published by Aleksandras Stulginskis University. This is an open-access article distributed under the terms of the Creative Commons Attribution License (CC-BY 4.0), which permits unrestricted use, distribution, and reproduction in any medium, provided the original author and source are credited. 
significantly on precipitation conditions. In dry years the regional yielding deficits accounted for, on average, 13 and maximum $27 \%$.

As for corn cultivation, it is possible to apply drip irrigation, facilitating fertigation and advanced automation based on a continuous weather conditions monitoring. The technology, next to favorable production effects, also ensures a more economical water management, as compared with sprinkling irrigation (Karasu et al., 2015, Kuśmierek-Tomaszewska et al., 2012, Lamm et al., 2007, Żarski et al., 2015).

The aim of the research was to develop a model determining production effects of corn irrigation depending on the indices characterizing moisture content during a period of corn vegetation.

\section{MATERIAL AND METHODS}

The paper is based on the data obtained from long-term rigorous field experiments with drip irrigation in corn grown for grain, carried out in 2005-2016. The experiments were carried out in the experimental field of the Department of Land Reclamation and Agrometeorology of the UTP University of Science and Technology in Bydgoszcz, Poland. The field is located at Mochełek, about $20 \mathrm{~km}$ away from the city center, on the south-eastern edge of the Krajeńska Upland $\left(\varphi=53^{\circ} 13^{\prime}, \lambda=17^{\circ} 51^{\prime}, \mathrm{h}=98,5 \mathrm{~m}\right.$ above sea level); in the zone with the highest average precipitation deficits and the high need for supplementary irrigation in Poland in terms of the climate criterion. The experiment was set up in Luvisol formed from fluvioglacial sands on shallow-deposited sandy clay loam, classified as IVa soil valuation class and as very good rye agricultural suitability complex. In terms of compaction it is sandy soil on compact subsoil. Considering the soil conditions of the experiment, irrigation was, typically for Poland's climate conditions, used in emergency, supplementing the seasonal precipitation deficits over the period of intensified water requirements of the crops tested.

The plants were optimally irrigated, ensuring the reserve of easily accessible water throughout the period of high water needs in the soil layer with controlled moisture level, which means that water needs of plants during the growing season were fully covered (the soil moisture was maintained in the range of $\mathrm{pF}$-value of 2.0-2.5). The irrigation dates were determined based on information from continuous soil root layer moisture monitoring, by balancing the reserve of readily available water based on the weather parameters and direct soil moisture measurements using Fieldscout TDR 300 Soil Moisture Meter probe. For grain corn irrigation the drip-line was applied with embedded, every $200 \mathrm{~mm}$ in the line wall, labyrinth emitters manufactured by NAAN, placed between the rows. The number of single irrigation rates and the total seasonal rate depended on the weather conditions pattern, mostly on precipitation distribution.

For the analysis were used yields of corn (irrigated $-\mathrm{W}$ and without the irrigation treatment $-\mathrm{O}$ ) obtained in the subsequent twelve years 2005-2016, and also data from meteorological monitoring, gained from the measurement point located in the vicinity of the experiment field. The measurements procedures are compliant with the WMO measuring standards and best practices. The analysis of correlation and regression were used to determine the most significant relationships between the production effects of irrigated corn in the subsequent years and selected indicators characterizing the moisture content during the period of high water needs of corn, ie. from 1 June to 31 July. The critical value of the correlation coefficient for number of paired observations $n=12$ at the significance level $\mathrm{p}=0.05$ is 0.576 . The following indicators were considered for the study: absolute precipitation (P), relative precipitation index (RPI) standardized precipitation index (SPI), described by Labędzki (2006) as well as the ratio of precipitation to potential evapotranspiration (ET) calculated with the Grabarczyk formula $E T=0.32(d+1 / 3 t)$, where $d$ - mean vapor pressure deficit in $\mathrm{hPa}, t$ - mean air temperature in ${ }^{\circ} \mathrm{C}$.

\section{RESULTS AND DISCUSSION}

In respective corn drip-irrigation research years the weather conditions over its intensified water requirements varied a lot. The total precipitation was, on average, $143.5 \mathrm{~mm}$, changing from $46.0 \mathrm{~mm}$ in 2006 as much as to $249.4 \mathrm{~mm}$ in 2012. The RPI ranged from 38 to $203 \%$, SPI from -1.66 to 1.87 , and the level of coverage of evapotranspiration by precipitation - from 0.12 to 1.26 . Four dry, three normal and five wet seasons were recorded. Under such precipitation conditions, irrigation was, typically for the climate of central Poland, applied in emergency cases (Rzekanowski et al., 2011, Żarski et al., 2017). The total irrigation rates ranged from $25-35 \mathrm{~mm}$ in wet seasons to $215-230 \mathrm{~mm}$ in dry seasons (Table 1). Unlike in the dry and semi-dry climate zones, where irrigation is a basic and indispensable yield-forming practice, in central Poland its role is to supplement precipitation deficits. Irrigation is applied mostly in the case of longer precipitation-less periods. There occur periods, and even the whole growing seasons, where it is applied very rarely or it is not applied at all; hence research aiming at improving irrigation in central Poland cover mostly the aspects of the purposefulness of its application and production and economic effectiveness, and not e.g. incomplete coverage of the water requirements in plants due to the water saving necessity (Karasu et al., 2015, Ko and Puccinni, 2009, Kuscu et al., 2013, Parizi et al., 2016).

Non-irrigated corn grain yields were, on average in the research years $9.10 \mathrm{tha}^{-1}$ (Table 2). In respective years the yields showed a very high variation; from 0.59 to $16.07 \mathrm{t}^{-1} \mathrm{a}^{-1}$. The coefficient of variation for them accounted for $89 \%$. The regression analysis (Figure 1) demonstrated that yielding depended significantly on moisture content over the period of high water needs in corn i.e. from June to July. Of all the indices analyzed, the strongest correlation with the grain yield in non-irrigated corn referred to the P/ET ratio (Figure 1), however, absolute precipitation and SPI determined the yield to a comparable significant degree. The polynomial regression equations (Figure 1) show that the optimal precipitation for corn in the period June through July was $220-230 \mathrm{~mm}$, and the P/ET ratio - 0.95-1.05. 
Table 1. Moisture content indicators and the total irrigation rates over the period of high water needs in corn (June-July)

\begin{tabular}{|c|c|c|c|c|c|c|c|}
\hline Year & $\begin{array}{c}\text { Drought intensities } \\
\text { acc. to SPI }\end{array}$ & $\begin{array}{c}\text { P } \\
\mathrm{mm}\end{array}$ & $\begin{array}{c}\text { RPI } \\
\%\end{array}$ & SPI & $\begin{array}{c}\text { ET } \\
\mathrm{mm}\end{array}$ & P/ET & $\begin{array}{c}\text { D } \\
\mathrm{mm}\end{array}$ \\
\hline 2005 & Moderately dry & 64.1 & 52 & -1.11 & 290 & 0.22 & 145 \\
\hline 2006 & Very dry & 46.0 & 38 & -1.66 & 372 & 0.12 & 120 \\
\hline 2007 & Moderately wet & 210.2 & 171 & 1.42 & 224 & 0.94 & 25 \\
\hline 2008 & Mild dry & 74.2 & 61 & -0.85 & 277 & 0.27 & 215 \\
\hline 2009 & Wet & 175.4 & 143 & 0.97 & 186 & 0.94 & 90 \\
\hline 2010 & Normal & 125.5 & 102 & 0.20 & 268 & 0.47 & 140 \\
\hline 2011 & Very wet & 233.3 & 190 & 1.69 & 221 & 1.06 & 30 \\
\hline 2012 & Very wet & 249.4 & 203 & 1.87 & 198 & 1.26 & 55 \\
\hline 2013 & Normal & 128.3 & 105 & 0.24 & 223 & 0.58 & 95 \\
\hline 2014 & Normal & 100.3 & 82 & -0.27 & 211 & 0.48 & 150 \\
\hline 2015 & Mild dry & 83.4 & 68 & -0.63 & 289 & 0.29 & 230 \\
\hline 2016 & Very wet & 231.9 & 189 & 1.68 & 278 & 0.83 & 35 \\
\hline Average & Normal & 143.5 & 117 & 0.49 & 253 & 0.57 & 110.8 \\
\hline
\end{tabular}

$\mathrm{P}$ - absolute precipitation, RPI - relative precipitation index, SPI-standardized precipitation index, P/ET-precipitation to potential evapotranspiration ratio, $\mathrm{D}-$ total irrigation rate

Corn grain yields under drip-irrigation conditions were on average $13.73 \mathrm{tha}^{-1}$, ranging in respective years from 9.72 to $16.71 \mathrm{tha}^{-1}$ (Table 2). Irrigation enhanced the yield stability since the coefficient of variation in the grain yield in irrigated corn accounted for $12 \%$.

Table 2. Grain yields and drip-irrigation effectiveness in corn depending on drought level

\begin{tabular}{|c|c|c|c|c|c|c|c|}
\hline Yield & SPI & \multirow{2}{*}{$\begin{array}{c}\text { Drought level } \\
\text { acc. to SPI }\end{array}$} & $\begin{array}{c}\text { Grain yield at } 15 \% \text { moisture } \\
\text { content }\left(\mathrm{tha}^{-1}\right)\end{array}$ & \multicolumn{2}{c|}{ Grain yield increase under irrigation } \\
\cline { 4 - 8 } & & & $\mathrm{O}$ & $\mathrm{W}$ & $\mathrm{tha}^{-1}$ & $\%$ & $\mathrm{~kg}^{-1} \mathrm{~mm}^{-1}$ \\
\hline 2006 & -1.66 & Very dry & 0.59 & 10.55 & 9.96 & 1688 & 83.0 \\
\hline 2005 & -1.11 & Moderately dry & 5.35 & 11.51 & 6.15 & 115 & 42.4 \\
\hline 2008 & -0.85 & Mild dry & 2.35 & 9.72 & 7.36 & 313 & 34.2 \\
\hline 2015 & -0.63 & Mild dry & 7.29 & 12.93 & 5.64 & 77 & 24.5 \\
\hline 2014 & -0.27 & Normal & 10.56 & 16.71 & 6.14 & 58 & 40.9 \\
\hline 2010 & 0.20 & Normal & 8.07 & 15.88 & 7.81 & 97 & 55.8 \\
\hline 2013 & 0.24 & Normal & 9.80 & 14.16 & 4.36 & 44 & 45.9 \\
\hline 2009 & 0.97 & Wet & 11.48 & 15.34 & 3.86 & 34 & 42.9 \\
\hline 2007 & 1.42 & Moderately wet & 10.98 & 12.19 & 1.21 & 11 & 48.4 \\
\hline 2016 & 1.68 & Very wet & 14.64 & 16.33 & 1.69 & 12 & 48.3 \\
\hline 2011 & 1.69 & Very wet & 16.07 & 16.45 & 0.38 & 2 & 12.7 \\
\hline 2012 & 1.87 & Very wet & 12.04 & 12.96 & 0.93 & 8 & 16.7 \\
\hline Average & 0.49 & Normal & 9.10 & 13.73 & 4.63 & 51 & 41.7 \\
\hline
\end{tabular}

$\mathrm{O}$ - control, $\mathrm{W}$ - irrigation treatment
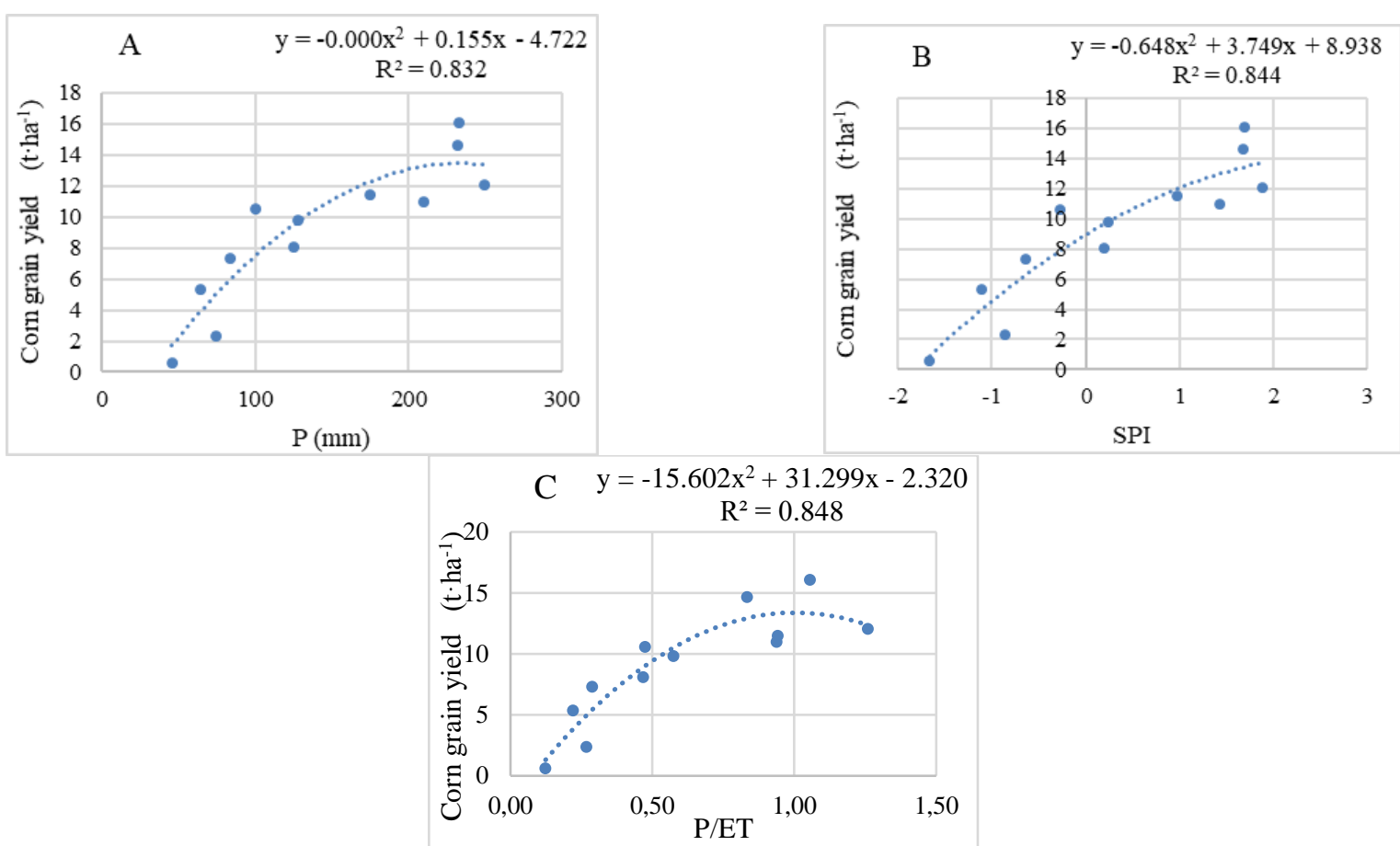

Figure 1. The relationship between the grain yielding of corn grown without irrigation in tha ${ }^{-1}$ and moisture conditions over the period of high water needs, A - precipitation, B - standardized precipitation index SPI, C - precipitation to evapotranspiration ratio 
The mean irrigation production effect was $4.63 \mathrm{tha}^{-1}$, which accounted for a $51 \%$ increase in the grain yield. $1.0 \mathrm{~mm}$ of irrigation water resulted in an average yield increase accounting for $41.7 \mathrm{~kg} \cdot \mathrm{mm}^{-1} \cdot \mathrm{ha}^{-1}$ ( Table 2). In successive years the irrigation production effects depended significantly, linearly and in inverse proportion on the precipitation indices (moisture content) in the periods of intensified water requirements in corn (Figure 2). The best indicator of those effects was absolute precipitation $\left(\mathrm{R}^{2}=0.852\right)$. The regression equation shows that increases in yields due to irrigation are non-significant only when precipitation in June through July exceeds $220-230 \mathrm{~mm}$ and the P/ET ratio exceeds the value of 1.20.
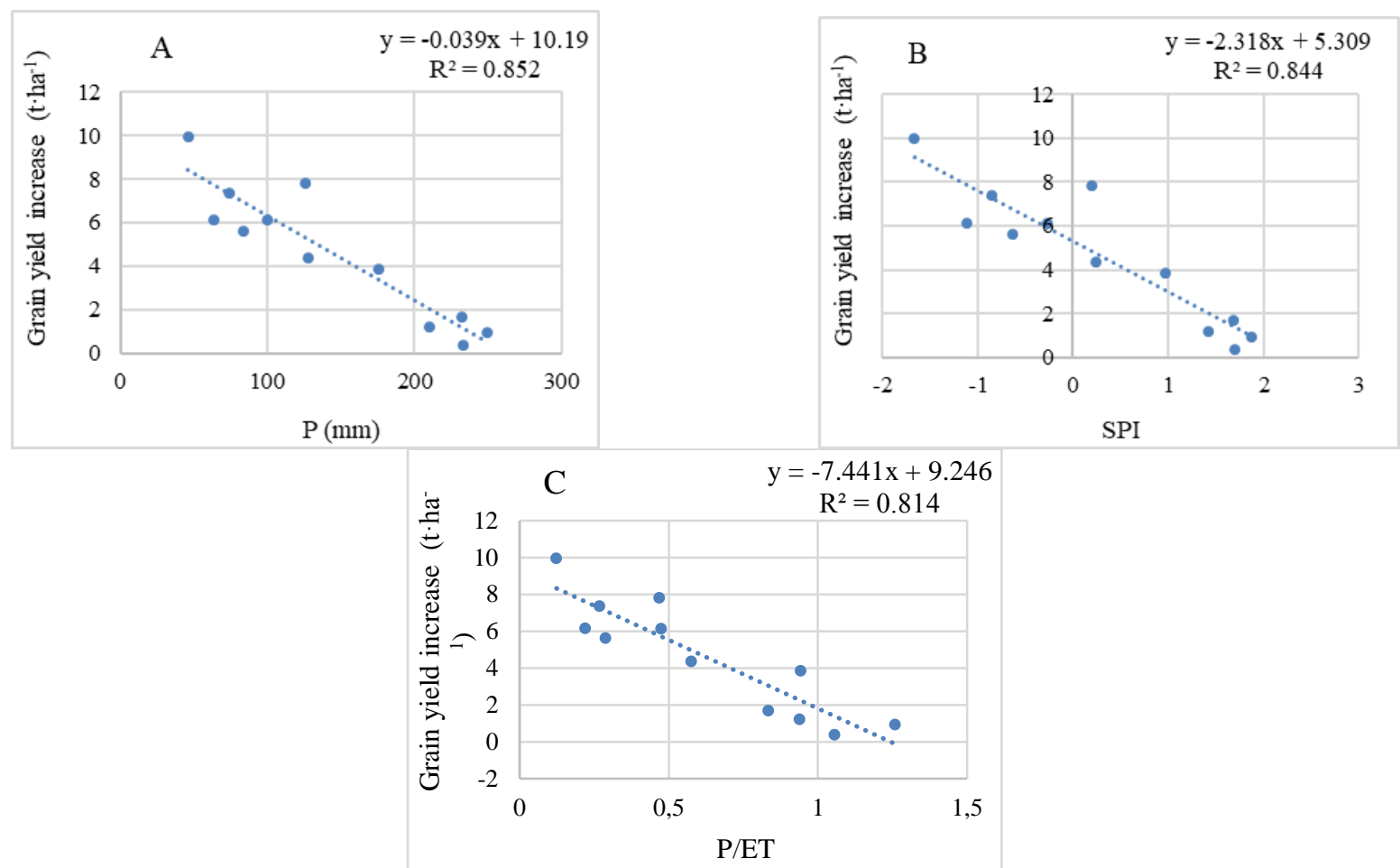

Figure 2. Linear relationship between corn grain yield increases due to irrigation in tha ${ }^{-1}$ and moisture conditions over the period of high water needs: A - precipitation, B - standardized precipitation index SPI, C - precipitation to evapotranspiration ratio

The average drip-irrigation production effects in corn recorded in the present research are difficult to achieve by applying other agrotechnical, land development and breeding practices. They point to a considerable increase in corn production if the water factor is optimized. Considering the results of the present study, introducing irrigation to corn production technology is a well-justified practice. However, in agricultural practice, making that treatment common will depend much on the economic conditions, which have an impact on grain prices; as well as on infrastructural conditions - mainly the availability of water sources for irrigation purpose (Rzekanowski et al., 2011, Żarski et al., 2013).

\section{CONCLUSIONS}

1. Presented results, based on the date from long term (2005-2016) field experiment with drip-irrigation in corn grown for grain in central Poland has demonstrated that the non-irrigated corn yields depended significantly on rainfall conditions and indicators characterizing moisture conditions. The results demonstrated a very high temporal variability.

2. Irrigation led to a significant $51 \%$ increase in yields and their stability in the years. Due to that practice, the coefficient of variation of the yield decreased from 89 to $12 \%$. The production effects of drip irrigation depended significantly on moisture conditions over the period of high water needs of corn from June to July. In wet seasons the increases in grain yields due to irrigation were non-significant and about four-fold lower, while in the dry periods - more than half higher than the average increases.

3. There is a high importance of the results presented in the paper, because they can be used as a model for forecasting corn production and its economic effects as well as for planning the development of irrigation systems in a given area.

\section{REFERENCES}

1. Dudek, S., Żarski, J., Kuśmierek-Tomaszewska, R. 2009. Reakcja kukurydzy na nawadnianie w świetle wyników wieloletniego eksperymentu polowego. Infrastruktura i Ekologia Terenów Wiejskich, Vol. 3, pp. 167-174. [In Polish]

2. Karasu, A., Kuscu, H., Oz, M., Bayram, G. 2015. The effect of different irrigation water levels on grain yield, yield components and some quality parameters of silage maize (Zea mays indentata Sturt.) in Marmara Region of Turkey. Notulae Botanicae Horti Agrobotanici Cluj-Napoca, Vol. 43(1), pp. 138-145. https://doi.org/10.15835/nbha.43.1.9602 
3. Ko, J., Piccinni, G. 2009. Corn yield responses under crop evapotranspiration-based irrigation management. Agricultural Water Management, Vol. 96, pp. 799-808. https://doi.org/10.1016/j.agwat.2008.10.010

4. Kuscu, H., Karasu, A., Oz, M., Demir, A., Turgut, I. 2013. Effect of irrigation amounts applied with drip irrigation on maize evapotranspiration, yield, water use efficiency, and net return in a sub-humid climate. Turkish Journal of Field Crops, Vol. 18(1), pp. 13-19.

5. Kuśmierek-Tomaszewska, R., Żarski, J., Dudek, S. 2012. Meteorological automated weather station data application for plant water requirements estimation. Computers and Electronics in Agriculture, Vol. 88, pp. 44-51. https://doi.org/10.1016/j.compag.2012.07.002

6. Lamm, F. R., Ayars, J. E., Nakayama, F. S. (Ed.) 2007. Microirrigation for Crop Production Design, Operation, and Management. Developments in Agricultural Engineering 13, 1-618.

7. Łabędzki, L. 2006. Susze rolnicze. Zarys problematyki oraz metody monitorowania i klasyfikacji. Wydawnictwo IMUZ, Falenty. [In Polish]

8. Łabędzki, L. 2009. Przewidywane zmiany klimatyczne a rozwój nawodnień w Polsce. Infrastruktura i Ekologia Terenów Wiejskich 3, 7-18. [In Polish]

9. Nagy, J. 2003. Effect of irrigation on maize yield (Zea mays L). Acta Agraria Debreceniensis, Vol. 11, pp. 1-6.

10. Parizi, A., Robaina, A., Gomes A., Peiter, M., Soares, F. 2016. Corn yield under various simulated irrigation depths. Engenharia Agrícola Jaboticabal, Vol. 36(3), pp. 503-514. https://doi.org/10.1590/1809-4430-Eng.Agric.v36n3p503-514/2016

11. Rolbiecki, S., Rolbiecki, R., Rzekanowski, C., Żarski, J. 2000. The influence of sprinkler irrigation on yields of some vegetable crops in the region of Bydgoszcz, Poland. Acta Horticulturae, Vol. 537, pp. 871-877. https://doi.org/10.17660/ActaHortic.2000.537.105

12. Rolbiecki, S., Rolbiecki, R., Kuśmierek-Tomaszewska, R., Dudek, S., Żarski, J., Rzekanowski, Cz. 2015. Requirements and effects of drip irrigation of mid-early potato on a very light soil in moderate climate. Fresenius Environmental Bulletin, Vol. 24(11b), pp. 3895-3902.

13. Rzekanowski, C., Żarski, J., Rolbiecki, S. 2011. Potrzeby, efekty i perspektywy nawadniania roślin na obszarach szczególnie deficytowych w wodę. Postępy Nauk Rolniczych, No. 1, pp. 51-63. [In Polish]

14. Wszelaczyńska, E., Pobereżny, J., Dudek, S., Kuśmierek-Tomaszewska, R., Żarski, J., Pawelzik, E. 2015. The effects of fertilizers, irrigation and storage on the properties of potato tubers and their constituent starches. Starch/Stärke, Vol. 67, pp. 478-492. https://doi.org/10.1002/star.201400196

15. Żarski, J., Dudek, S., Kuśmierek-Tomaszewska R., Rolbiecki, R., Rolbiecki, S. 2013. Prognozowanie efektów nawadniania roślin na podstawie wybranych wskaźników suszy meteorologicznej i rolniczej. Annual Set The Environment Protection, Vol. 15, pp. 2185-2203.

16. Żarski, J., Dudek, S., Grzelak, B., Kuśmierek-Tomaszewska, R., Rolbiecki, R., Rolbiecki,S. 2015. Wpływ nawadniania i fertygacji kroplowej azotem na plonowanie kukurydzy na obszarze szczególnie deficytowym w wodę. Infrastruktura i Ekologia Terenów Wiejskich, Vol. II/1, pp. 279-289. [In Polish]

17. Żarski, J., Kuśmierek-Tomaszewska R., Dudek, S. 2016. Trends of changes in climate risk of grain maize cultivation in the Bydgoszcz Region. Infrastructure and Ecology of Rural Areas, Vol. III, No. 1, pp. 725-735.

18. Żarski, J., Dudek, S., Kuśmierek-Tomaszewska, R., Żarski, W. 2017. Effects of agricultural droughts in the province of KujawskoPomorskie and possibilities of minimizing their impact. Infrastructure and Ecology of Rural Areas, Vol. II, No. 2, pp. 813-824. 